\title{
Global Banking: Transformation, Innovation \& Competition
}

\author{
Yury Korobov ${ }^{1, *}$ \\ ${ }^{1}$ Saratov Socio-Economic Institute (branch of Plekhanov Russian Economic University), Department \\ of Banking, Money \& Credit, 410017 Saratov, Russia
}

\begin{abstract}
The article discusses the main transformation processes in banking sector: globalization, concentration of capital, formation of a new model of banking and new banking culture. It is shown that the driving forces of these processes are competition and innovation. The interpretation of the bank of the future as a sum of four concepts is offered: "Bank = technology", "Bank = client", "Bank = product", "Bank = life". It is hypothesized that a person in the digital economy can be described as Homo financial (a person with financial literacy and financial thinking).

Key words: globalization, banking sector, transformation processes, innovation, competition
\end{abstract}

\section{Introduction}

We live in a constantly changing world. Everything is in a change - social relations, technology, economy, - and the banking sector is not an exception. Moreover, the changes which are currently taking place in the banking sector are often not evolutionary, but revolutionary. The depth of these changes is such that they should be considered not as modernization, but as transformation.

One of the main driving forces of these transformations is the development of competition, which encourages banks to evolve and search for the optimal business model, as well as actively introduce innovations - to expand the range of banking products and services, improve the quality of service, and maximize the use of opportunities of new information technologies.

The most important transformation processes in banking sector, in my opinion, are:

- Globalization;

- Growth of capital concentration;

- Formation of a new model of banking;

- Formation of a new banking culture.

The purpose of the article is to disclose the content of the listed transformation processes and to show their influence on the essence of the bank of the future.

\footnotetext{
*Corresponding author: yurikor1965@gmail.com
} 


\section{Background}

Various problems of globalization and its relationship to competition and innovations have been discussed in many publications, including, [1], [2], [3].

Issues of financial globalization and its impact on competition and capital concentration in banking sector have been revealed [4], [5], [6], [7].

Among studies concerning formation of the new model of banking should be mentioned publications [8], [9], as well as the author of this article [10,11].

However, in general, it should be noted that the issues of the essence of the bank of the future, as well as the formation of a new banking culture, are not sufficiently studied in the scientific literature. This determines the relevance of the topic of this article.

\section{Globalization in banking sector}

One of the most important forms of globalization processes in the end of $20^{\text {th }}$ - beginning of $21^{\text {st }}$ century is the financial globalization. The main reasons for this are differences in the level of profitability and risks in individual countries, increased mobility of financial resources, as well as the development of the digital economy, which allows to easily overcome the boundaries between countries and regions.

The process of globalization forces to reconsider the established idea of the essence of the banking system. Traditionally, in the economic literature, the banking system used to be defined as the set of credit institutions within a specific country [12, 13, 14]. But this interpretation is correct only for the national banking system. Globalization leads to increased interdependence of banking systems of different countries, up to the formation of an international banking system. And this is a new, higher level of banking systems' development.

In the context of globalization, there is a need to improve the institutional structure of the national banking system by developing a modern banking infrastructure (including upgrading of its information subsystem, increasing the transparency of the banking market) and modernizing the regulation of the banking sector (creation a uniform standard for the regulation of banks and non-bank credit institutions, adoption of measures to combat unfair competition and curb monopolistic tendencies, etc.).

\section{Concentration of capital in global banking}

The current period of time is characterized by the transition from the extensive model of the banking network development to the intensive one. While in the $20^{\text {th }}$ century in many countries (including Russia) there was a significant increase in the number of commercial banks and a rapid expansion of their branch network, the main trends of the $21^{\text {st }}$ century are the increase in the bank capital concentration and the rationalization of the branch network.

The concentration of capital and assets in Russian banking system is particularly high. The overwhelming share of assets (more than 98\%) is concentrated in the 200 largest banks (i.e., about $30 \%$ of operating banks). Even more impressive is the degree of concentration calculated for the 5 largest banks (among which Sberbank occupies a special place): they account for more than $50 \%$ of assets. Taking into account the dynamics of recent years, we should not expect these indicators to decrease. 


\section{A new model of banking}

For many hundreds of years, banks have undergone a profound evolution. Initially, they acted as infrastructure organizations performing the functions of redistributing financial resources, managing issue and circulation of money. This model of banking could be called the traditional model. It is based on the concept "Bank = institution".

The development of bank competition in the $20^{\text {th }}$ century led to the transformation of a commercial bank into a producer that meets the financial needs of customers. Such a banking model could be called the marketing model. It is based on the concept "Bank= enterprise".

What difference does it make to consider a bank an institution or an enterprise? The answer to this question is not only of theoretical issue, but also of big practical importance. The way how the bank managers and employees perceive the essence of a bank largely affects the policy of the bank, its relationship with customers [11].

When a bank is perceived as an institution, then bank employee is a clerk, and customer is a petitioner. This corresponds to the administrative type of relationship between banks and clients.

When a bank is perceived as an enterprise, then bank employee is a producer, and customer is a buyer. This is a completely different, partner type of relationship between the banks and clients.

Now, under the influence of competition and innovation, a new model of banking is being formed [8, 11]. What will be the concept behind this model? A simple and unambiguous answer is hardly possible here. In my opinion, the model of the bank of the future will be characterized by the set of several concepts.

\subsection{Introduction of new technologies (the concept "Bank = technology")}

In many publications, the bank of the future is considered as a technological phenomenon. And, indeed, the list of new devices and technologies implemented in banks is impressive.

First of all, the bank of the future will be characterized by even more extensive use of automation. Already today, banks are using video registration and biometrics systems, video consultations and self-service kiosks, interactive displays and touch-screen tables, electronic cashiers and automatic depositories, devices for contactless payments and electronic signatures, etc.

An increasing number of banking products is sold on the basis of remote technologies. Today, bank customers can gain access to basic banking services using Internet banking and mobile banking, however to open an account, you still have to come to the bank in person. But the introduction of digital identity identification can relieve customers from this.

Another way of technological development is the introduction of banking robots. Some of them are material devices representing the next evolution stage of ATMs, and some are purely virtual - like chat bots capable to communicate with customers via special applications.

All this forms a new image of the bank and a new quality of service. But the model of the bank of the future is not limited only to technological changes.

\subsection{Increasing customer self-sufficiency (the concept "Bank = customer")}

The introduction of remote banking services and increasing the financial literacy of population lead to the increase in the number of transactions that a client performs independently, without the involvement of bank employee. 
The development of Internet information services makes it possible to provide a high degree of independence and freedom for bank customers who have the opportunity to compare the products of different banks and - to some extent - to design their own banking products. A financially literate client in the digital economy can become a "bank for oneself".

\subsection{Transfer of customer's attention from banks to banking products (the concept "Bank = product")}

For an independent and competent customer, the product is in the foreground, not the provider. Therefore, attracting the attention of customers is of particular importance for banks.

The development of non-banking payment systems, the creation of social networks in the field of finance and credit, the outsourcing of banking services lead to the increasing blurring of the boundaries between banks and non-bank credit organizations.

Also, we witness the expansion of the financial supermarket model in which a customer can get the widest possible range of financial products (banking, investment, insurance, etc.) "under one roof".

\subsection{Integration of banks into people's everyday life (the concept "Bank = life")}

Even today, a bank is not an ordinary enterprise, akin to a manufacturing or trade company, but a socially-oriented institution whose objective is not only to obtain profit.

The contemporary banks are engaged in charitable activities, give support for social initiatives. All this creates a positive image of the bank and a favorable social atmosphere for its activities, a "climate of trust".

In addition, the social role of banks is evident in the fact that, in order to attract customers, banks are making efforts to increase the financial literacy of population. Means of this are promotional publications (leaflets, brochures) which explain the content of certain banking products, information and analytical publications in mass media, as well as participation in educational events aimed to increase the financial literacy.

A separate area of banking that affects the level of financial literacy in society is the development of banking for children. Most banks today offer products (cards, deposits, loans), the target audience of which are children. Some banks go further by funding educational projects, development and publication of educational materials.

The logical conclusion of the integration of banking services into people's everyday life in the digital economy is the model of lifestyle banking, when the bank becomes an integral element of human life.

One of the manifestations of this is banking design. Banks endeavor to make the appearance of their buildings attractive, as well as the interior of banking premises.

Banks tend to make visiting their offices for customers as convenient and enjoyable as possible by offering them something more than just banking services.

The most famous example of such a strategy is the activity of Umpqua Bank (Portland, Oregon, USA). To change the attitude of customers to the bank, its CEO Ray Davis decided to use a model of retail company, turning banking into shopping, and bank branches into financial shops [15].

Moreover, today banks are no longer limited to financial services, evolving into diversified service companies. For example, Sberbank plans to provide public services in its offices, up to issuing civil passports.

Thus, the bank of the future combines such concepts as "Bank = technology", "Bank= customer", "Bank = product", "Bank = life". Banks become different both externally, and 
internally. At the same time, the society is changing - a new banking culture is being formed.

\section{A new banking culture}

Banking culture is one of new and insufficiently researched phenomena. Often it is treated as a kind of corporate culture, which is a system of intra-bank values, a set of principles for the bank's activities or rules of conduct for its employees. Carriers (subjects) of banking culture in this case are banks and bank employees. From this point of view, the banking culture looks like a phenomenon that has only local significance for the banking community.

This interpretation seems to be too narrow. It would be appropriate to the term "culture of a bank", but the term "banking culture" has a richer content. In my opinion, the carriers (subjects) of the banking culture are not only banks, but also other subjects involved in relations with banks - namely banking customers, and society represented by the central bank and other social institutions (legislative bodies, state regulation institutions, infrastructure organizations, etc.).

Thus, banking culture in the broadest sense can be defined as a set of principles of behavior of all subjects of banking activity - banks, banking customers and social institutions that ensure the functioning of the banking system.

According to this, there are three levels of banking culture [16]: corporate banking culture, consumer banking culture and social banking culture.

The elements of the corporate banking culture are the internal banking rules (appearance, rules of conduct in the workplace, correspondence, telephone conversations), a set of professional competencies of bank employees, the culture of communication with customers, corporate identity (branding), management culture (leadership style), banking strategy, culture of competition, principles of relations with the state and society.

Elements of consumer banking culture are the financial literacy of bank customers and their willingness to use banking services.

It is important to note that only the awareness of potential customers about the range of banking services is not enough. Banking services don't meet the primary production and personal needs, but the financial needs derived from them. Therefore, the motivation to acquire banking services from potential customers is much lower than to purchase material goods; the needs for banking services are often latent in nature, they need to be awakened. Creating incentives for more active and efficient consumption of banking products is an important task, both from the point of view of the banks themselves and from the point of view of society.

Elements of social banking culture are banking legislation, the development strategy of the banking system, regulation of bank competition (antitrust measures, combating unfair competition), banking supervision, banking culture of the mass-media.

The high risks inherent to the banking system call for the regulation of its activity by the state, and a calm and balanced attitude from mass-media.

The levels of banking culture are not separate from each other, but are interrelated. The content of intra-bank rules is influenced by the level of culture of banking customers and the framework conditions set by regulatory bodies. The task of increasing the financial literacy of clients is important for both banks and the state. The lack of the social banking culture (for example, inaction in the face of a banking crisis) can have devastating impact on both banks and their customers.

Thus, the formation of a new model of banking culture is not a local process, which is important and interesting only for bankers. Everyone who is interested in the successful and 
stable functioning of the banking system, as well as improving their financial well-being, should understand the banking culture.

The formation of a new banking culture, along with the transformation of the bank into an element of lifestyle, make it possible to state the hypothesis that the person of the digital economy is no longer just Homo sapiens (an intelligent person who appeared hundreds of thousands years ago) or even Homo economicus (economically-minded person formed in the conditions of development of the market economy), but Homo financial (a person with financial literacy and financial thinking).

\section{Conclusion}

A special feature of the development of the banking sector in modern conditions are transformation processes - globalization, capital concentration, formation of a new model of banking and a new banking culture. The driving forces of these transformations are competition and innovation.

The result of all the transformations should be the emergence of the bank of the future, the essence of which can be represented as the sum of four concepts: "Bank = technology", "Bank = client", "Bank = product", "Bank = life". It is hypothesized that a person in the digital economy can be described as Homo financial (a person with financial literacy and financial thinking).

\section{References}

1. Y. Gorodnichenko, J. Svejnar, K. Terrell, Globalization and innovation in emerging markets. IZA Discussion Paper, 3299 (2008)

2. D. D. Dorn, G. H. Hanson, G. Pisano, P. Shu, Foreign competition and domestic innovation: evidence from U.S. patents. NBER Working Paper, 22879 (2016)

3. M. Vokoun, Globalization and Innovation: Innovation activities of multinationals in the Czech Republic 1998-2010. Globalization and Its Socio-Economic Consequences. 16th International Scientific Conference Proceedings, 5 (2016)

4. J. Tobin, Financial Globalization. World Development, 28(6) (2000)

5. A. N. Berger, R. DeYoung, H. Genay, G. F. Udell, Globalization of financial institutions: evidence from cross-border banking performance. Brookings-Wharton Papers on Financial Services, 3 (2000)

6. E. S. Prasad, K. Rogoff, S.-J. Wei, M. A. Kose, Effects of financial globalization on developing countries: some empirical evidence. IMF Occasional Paper; 220 (2003)

7. R. M. Stulz, Presidential address: the limits of financial globalization. The Journal of Finance, 60(4) (2005)

8. B. King, Bank 3.0: Why banking is no longer somewhere you go, but something you do. Marshall Cavendish, (2012)

9. G. Wehinger, Banking in a challenging environment: Business models, ethics and approaches towards risks. OECD Journal, 2 (2012)

10. Y. I. Korobov, Развитие банковской системы: модернизация или трансформация [Development of the banking system: modernization or transformation]. Наука $и$ общество [Science and Society], 3 (2015)

11. Y. I. Korobov, Сущность банка и ее эволюция в современных условиях [The essence of the bank and its evolution in modern conditions]. Банковские услуги [Banking Services], 7-8 (2005) 
12. O. I. Lavrushin, Деньги, кредит, банки [Money, credit, banks], $15^{\text {th }}$ ed., KnoRus, (2016)

13. Ch. Pass, B. Lowes, L. Davies, Collins Dictionary of Economics, 4th ed., Glasgow: HarperCollings (2005)

14. BusinessDictionary, Banking system [online]. Available at: http://www.businessdictionary.com/definition/banking-system.html (2017)

15. R. P. Davis, A. Shrader, Leading for Growth: How Umpqua Bank Got Cool and Created a Culture of Greatness. Jossey-Bass, (2007)

16. Y. I. Korobov, Новое понимание банковской культуры [New understanding of banking culture], Финансы и кредит [Finance and Credit], 15 (2012) 
